\title{
PENDAMPINGAN SURVEY KONDISI MASYARAKAT PADA MASA PANDEMI COVID-19 DI RT 03 KELURAHAN KANDANG LIMUN KOTA BENGKULU
}

\author{
Dyah Setyo Rini ${ }^{1}$, Ulfasari Rafflesia ${ }^{2}$, Nur Afandi ${ }^{3}$, Indah Wahyuliani ${ }^{4}$ \\ 1,4 Program Studi Statistika, FMIPA, Universitas Bengkulu, Bengkulu, Indonesia \\ ${ }^{2,3}$ Program Studi Matematika, FMIPA, Universitas Bengkulu, Bengkulu, Indonesia \\ E-mail: dyah.setyorini@unib.ac.id \\ Received September 2020, Accepted October 2020
}

\begin{abstract}
ABSTRAK
Penyebaran Covid-19 dinyatakan telah masuk ke Kota Bengkulu pada tanggal 31 Maret 2020. Sejak saat itu berbagai upaya pencegahan penyebaran Covid-19 dilakukan, diantaranya memperketat pengawasan orang luar masuk ke wilayah Bengkulu terutama yang berasal dari zona merah Covid-19 dan sebaliknya serta mengimbau masyarakat untuk menjaga jarak antara 1-1,5 meter jika berinteraksi dengan orang lain. Berdasarkan situasi tersebut, Lurah Kandang Limun ingin mengetahui bagaimana kondisi masyarakat di Kandang Limun dalam masa pandemi ini. Hal itu dilakukan sebagai upaya pencegahan penularan Covid-19 serta merupakan dasar bagi Lurah untuk mengambil kebijakankebijakan untuk mencegah dan mengedukasi masyarakat sekitar kelurahan Kandang Limun. Oleh karena itu, kelurahan setempat meminta pendampingan dalam melakukan survey tentang kondisi masyarakat pada masa pandemi Covid-19. Melalui kegiatan ini diharapkan perangkat Kelurahan Kandang Limun mampu melakukan survey secara mandiri dan menyajikan informasi hasil survey dengan baik dan benar. Berdasarkan kegiatan pengabdian kepada masyarakat ini diperoleh bahwa masa pandemi Covid-19 ini cukup mempengaruhi aktifitas warga RT 03 Kelurahan Kandang Limun. Serta Perangkat RT 03 dan Kelurahan Kandang Limun dapat menyajikan data yang diperoleh dalam bentuk grafis yang mudah dipahami oleh warga.
\end{abstract}

Kata Kunci : Pendampingan Survey, Pandemi Covid-19, Kelurahan Kandang Limun

\section{ABSTRACT}

COMMUNITY CONDITION SURVEY ASSISTANCE IN PANDEMIC COVID-19 AT RT 03 KELURAHAN KANDANG LIMUN KOTA BENGKULU. The spread of Covid-19 was declared to have entered Bengkulu City on March 31, 2020. Since then various efforts to prevent the spread of Covid-19 were carried out, including tightening the supervision of outsiders entering the Bengkulu area, especially those from the Covid19 red zone and vice versa and appealing to community to maintain a 
distance of 1-1.5 meters when interacting with other people. Based on this situation, the Head of Kandang Limun Village wanted to know the condition of the people in Kandang Limun during this pandemic. This was done as an effort to prevent the transmission of Covid-19 and was the basis for the Village Head to take policies to prevent and educate the community around the Kandang Limun village. Therefore, the local urban village asked for assistance in conducting a survey about the condition of the community during the Covid-19 pandemic. Through this activity, it is hoped that the Kandang Limun sub-district apparatus will be able to carry out surveys independently and present survey information properly and correctly. Based on this community service activity, it was found that the Covid-19 pandemic had quite an impact on the activities of the residents of RT 03 Kandang Limun Village. As well as RT 03 and Kandang Limun subdistrict devices, they can present the data obtained in graphic form that is easily understood by residents.

Keywords : Survey Assistance, Pandemic Covid-19, Kelurahan Kandang Limun

\section{PENDAHULUAN}

Corona virus merupakan keluarga besar virus yang menyebabkan penyakit pada manusia dan hewan. Pada manusia biasanya menyebabkan penyakit infeksi saluran pernapasan, mulai flu biasa hingga penyakit yang serius seperti Middle East Respiratory Syndrome (MERS) dan Sindrom Pernafasan Akut Berat/ Severe Acute Respiratory Syndrome (SARS). Coronavirus jenis baru yang ditemukan pada manusia sejak kejadian luar biasa muncul di Wuhan Cina, pada Desember 2019, kemudian diberi nama Severe Acute Respiratory Syndrome Coronavirus 2 (SARS-COV2), dan menyebabkan penyakit Coronavirus Disease-2019 (Covid-19). Covid-19 disebabkan oleh SARS-COV2 yang termasuk dalam keluarga besar coronavirus yang sama dengan penyebab SARS pada tahun 2003, hanya berbeda jenis virusnya. Gejalanya mirip dengan SARS, namun angka kematian SARS (9,6\%) lebih tinggi dibanding Covid-19 (kurang dari 5\%), walaupun jumlah kasus Covid-19 jauh lebih banyak dibanding SARS. Covid-19 juga memiliki penyebaran yang lebih luas dan cepat ke beberapa negara dibanding SARS (Wikipedia, 2020).

Pada 30 Januari 2020, WHO mendeklarasikan status wabah Covid19 sebagai Darurat Kesehatan Global untuk keenam kalinya sejak Wabah flu babi 2009. Ini diakibatkan karena risiko penyebaran global, terutama ke negara-negara berpenghasilan rendah dan menengah tanpa sistem kesehatan yang kuat serta kurang mampu melakukan pengawasan setelah kemungkinan penularan dari manusia ke manusia terkonfirmasi. Penyebaran dan penularan Covid-19 dalam skala besar dan cepat menyebabkan World Health Organization (WHO) menetapkan penyebaran Covid-19 sebagai pandemi. Oleh karena itu, WHO menginstruksikan agar negara-negara berupaya mengurangi terjadinya penularan (WHO, 2020). 
Pemerintah Indonesia juga menyatakan masalah virus Corona sudah menjadi bencana nasional non alam.

Penyebaran Covid-19 dinyatakan telah masuk ke Kota Bengkulu pada tanggal 31 Maret 2020. Sejak saat itu berbagai upaya pencegahan penyebaran Covid-19 dilakukan, diantaranya memperketat pengawasan orang luar masuk ke wilayah Bengkulu terutama mereka yang berasal dari zona merah Covid-19 dan sebaliknya serta mengimbau masyarakat untuk menjaga jarak antara 1-1,5 meter jika berinteraksi dengan orang lain. Berdasarkan situasi tersebut, Lurah Kandang Limun ingin mengetahui bagaimana kondisi masyarakat di Kandang Limun dalam masa pandemi ini. Hal itu dilakukan sebagai upaya pencegahan penularan Covid-19 serta merupakan dasar bagi Lurah untuk mengambil kebijakan-kebijakan untuk mencegah dan mengedukasi masyarakat sekitar kelurahan Kandang Limun. Oleh karena itu, kelurahan setempat meminta pendampingan dalam melakukan survey tentang kondisi masyarakat pada masa pandemic Covid-19.

Kelurahan Kandang Limun Kota Bengkulu memiliki jumlah penduduk sebanyak 6357 Jiwa (1401 Kepala Keluarga) yang tersebar di 5 RW dan 21 RT. Kegiatan pendampingan survey ini dilakukan pada salah satu RT yang ada di Kelurahan Kandang Limun, yaitu RT 03. RT 03 Kelurahan Kandang Limun terdiri dari 75 Kepala Keluarga yang sebagian besar memiliki mata pencaharian sebagai pedagang. Pada masa new normal ini, hampir seluruh masyarakat RT 03 telah melakukan aktivitas di luar rumah. Oleh karena itu, RT 03 dipilih sebagai tempat dilakukannya pendampingan survey melalui program kerja individu salah satu mahasiswa Kuliah Kerja Nyata (KKN) Mandiri Universitas Bengkulu Periode 91.

Survey merupakan bentuk dasar kuantitatif. Penelitian survey menanyakan kepada beberapa responden tentang kepercayaannya, pendapat-pendapat, karakteristik, dan perilaku yang telah atau sedang terjadi. Survey menyediakan pertanyaan-pertanyaan untuk penelitian tentang laporan keyakinan/kepercayaan atau perilaku diri. Pertanyaanpertanyaan tersebut menjadi lebih tajam ketika responden memberikan jawaban-jawaban atas suatu pertanyaan-pertanyaan dengan variabelvariabel yang dikehendaki. Pada waktu melakukan survey biasanya peneliti menanyakan tentang beberapa hal, antara lain: ukuran beberapa variabel (seringkali dengan berbagai indikator), dan beberapa uji hipotesis dalam suatu survey tunggal. Meskipun suatu kategori bersifat tumpang tindih, beberapa pertanyaan dapat disertakan pada suatu survey, yaitu berkenaan dengan: 1) perilaku; 2) sikap, pendapat, keyakinan/kepercayaan; 3) karakteristik; 4) ekspektasi; 5) pengklasifikasian, dan 6) pengetahuan. Informasi dikumpulkan dari responden dengan menggunakan kuesioner. Umumnya penelitian survey dibatasi pada penelitian yang datanya dikumpulkan dari sampel atas populasi untuk mewakili seluruh populasi. Pada umumnya yang merupakan unit analisa dalam penelitian survey adalah individu. 


\section{MATERI DAN METODE}

Dalam rangka mencapai target dalam menyelesaikan permasalahan, maka metode yang digunakan dalam kegiatan pengabdian pada masyarakat ini adalah pendampingan. Metode pendampingan memiliki tahap-tahap, yaitu persiapan, pelaksanaan, dan penyajian hasil survey. Tahapan-tahapan yang dilakukan adalah :

\section{Tahap Persiapan}

a. Koordinasi tim dan Lurah Kandang Limun untuk melaksanakan kegiatan.

b. Koordinasi tim dengan LPPM Universitas Bengkulu.

c. Penyusunan rencana dan jadwal kegiatan serta dilakukan pembagian tugas kerja anggota tim.

d. Pembuatan WhatsApp Group (WAG) yang beranggotakan $75 \mathrm{KK}$ atau anggota keluarga yang berdomisili di RT 03 Kandang Limun.

\section{Tahap Pelaksanaan}

Pengabdian kepada masyarakat melalui pendampingan ini akan dilakukan secara online pada Bulan Juli. Adapun rencana kegiatan yang akan dilaksanakan adalah sebagai berikut:

a. Pendampingan penyusunan instrumen survey online dengan menggunakan Google Form. Pada kegiatan ini, tim berdiskusi dengan pemerintah setempat mengenai hal - hal yang dapat mencerminkan kondisi masyarakat RT 03 Kandang Limun pada masa pandemi Covid-19.

b. Percobaan pengisian instrumen survey online oleh perangkat Kelurahan Kandang Limun. Kegiatan ini bertujuan untuk memberikan petunjuk pengisian instrumen survey online dan mengetahui hasil isian instrumen tersebut.

c. Pendampingan penyebaran instrumen survey melalui WAG yang telah dibuat sebelumnya. Dalam kegiatan ini, tim membantu pemerintah setempat jika ada masyarakat yang belum mengerti dalam mengisi instrumen survey secara online.

\section{Tahap Penyajian Hasil Survey}

Pada tahap ini, tim pengabdian kepada masyarakat memberikan bantuan penyajian hasil survey supaya memiliki tampilan yang menarik dan dapat dimengerti oleh pembaca.

\section{Penelitian Survey}

Menurut estimologi, survey berasal dari Bahasa Latin terdiri dari suku kata sur yang merupakan turunan dari kata Latin super yang berarti di atas atau melampaui. Sedangkan suku kata vey berasal dari kata latin 
videre yang berarti melihat. Jadi kata survey berarti melihat di atas atau melampaui (Leedy, 1980, dalam Soehartono, 2000). Margono (2005) mendefinisikan metode peelitian survey adalah pengamatan/penyelidikan yang kritis untuk mendapatkan keterangan yang terang dan baik terhadap suatu persoalan tertentu dan di dalam suatu daerah tertentu. Penelitian survey umumnya bertujuan untuk mencapai generalisasi, dan sebagian lain juga untuk membat prediksi. Berdasarkan beberapa pendapat tersebut, dapat didimpulkan bahwa penelitian survey adalah salah satu metode penelitian yang umumnya mengkaji populasi yang besar dengan menggunakan sampel populasi yang bertujuan untuk membuat deskripsi, generalisasi, atau prediksi tentang opini, perilaku, dan karakteristik yang ada dalam populasi tersebut.

Tujuan dari penelitian survey adalah untuk mengumpulkan data primer yang dikumpulkan untuk penyelesaian suatu penelitian. Survei adalah metode pengumpulan data dengan mengambil sebagian objek populasi tetapi dapat mencerminkan populasi dengan memperhatikan keseimbangan antara jumlah variabel, akurasi, tenaga, waktu dan biaya.

\section{Penyajian Data Statistik}

Data statistik tidak hanya cukup dikumpulkan dan diolah, tetapi juga perlu disajikan dalam bentuk yang mudah dibaca dan dimengerti oleh pengambil keputusan. Penyajian data dapat dilakukan dalam bentuk tabel atau diagram dengan pertimbangan data tersebut dapat dengan mudah ditangkap dan dipahami oleh pembaca dibandingkan hanya disajikan dalam sekumpulan angka atau penjelasan kata-kata. Penyajian dalam bentuk tabel atau diagram akan membuat proses pengambilan keputusan lebih tepat, cepat dan akurat (Supranto, 2000).

\section{Statistika Deskriptif}

Statistika deskriptif merupakan bagian dari statitika yang mempelajari alat, teknik, atau prosedur yang digunakan untuk menggambarkan atau mendeskripsikan kumpulan data atau hasil pengamatan. Data yang dikumpulkan tersebut perlu disajikan supaya mudah dimengerti, menarik, komunikatif, dan informatif bagi pihak lain. Bentuk-bentuk penyajian data tersebut secara umum dibagi dalam dua aspek, yaitu (1) penyiapan data yang mencakup proses editing, pengkodean, dan pemasukkan data, serta (2) analisis pendahuluan meliputi pemilahan, pemeriksaan, dan penyusunan data sehingga diperoleh gambaran, pola, dan hubungan yang lebih bermakna (Walpole, 2012).

Analisis deskripsi data adalah upaya menampilkan data agar dapat dipaparkan secara baik dan diinterpretasikan secara mudah. Deskripsi meliputi penyusunan data dalam bentuk yang mudah dibaca secara lengkap. Tabel frekuensi merupakan cara penyajian yang paling umum untuk deskripsi data dan digunakan untuk peubah katagorik. Tabel ini 
menampilkan katagori-katagori yang muncul dalam gugus data beserta frekuensi masing-masing (Saeffudin dkk, 2009).

\section{HASIL DAN PEMBAHASAN}

Persiapan kegiatan pendampingan survey dimulai dengan melakukan koordinasi dengan Kelurahan dan RT 03 Kandang Limun. Kemudian tim juga berkoordinasi dengan pihak LPPM Universitas Bengkulu tentang kegiatan pendampingan yang akan dilaksanakan. Karena kegiatan ini dilakukan pada masa pandemi Covid-19, maka kegiatan koordinasi yang dilakukan tetap mengikuti protokol pencegahan penyebaran Covid-19 (misalnya social distancing dan menggunakan masker). Selain itu agar kegiatan pendampingan berjalan lancar, juga dilakukan koordinasi tim pelaksana dan bimbingan terhadap mahasiswa KKN. Setelah melakukan koordinasi, tahap persiapan yang dilakukan selanjutnya adalah pembuatan WhatsApp Group (WAG) yang beranggotakan $75 \mathrm{KK}$ atau anggota keluarga yang mewakili.

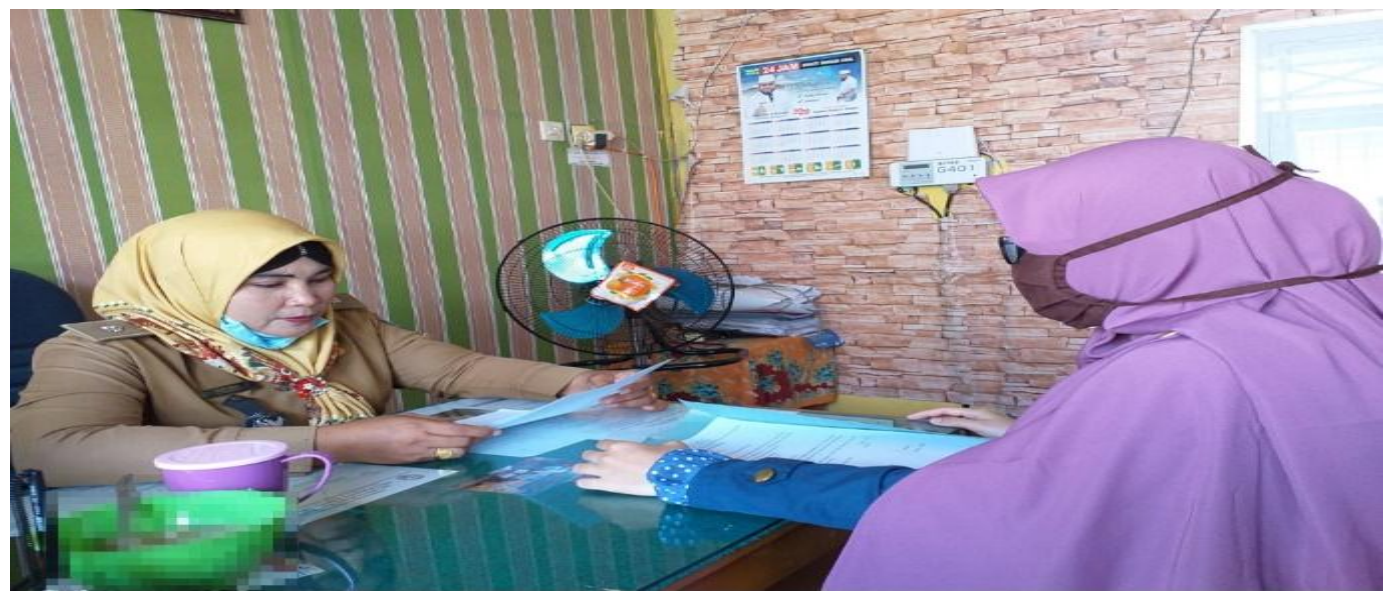

Gambar 1. Koordinasi dengan Lurah Kandang Limun

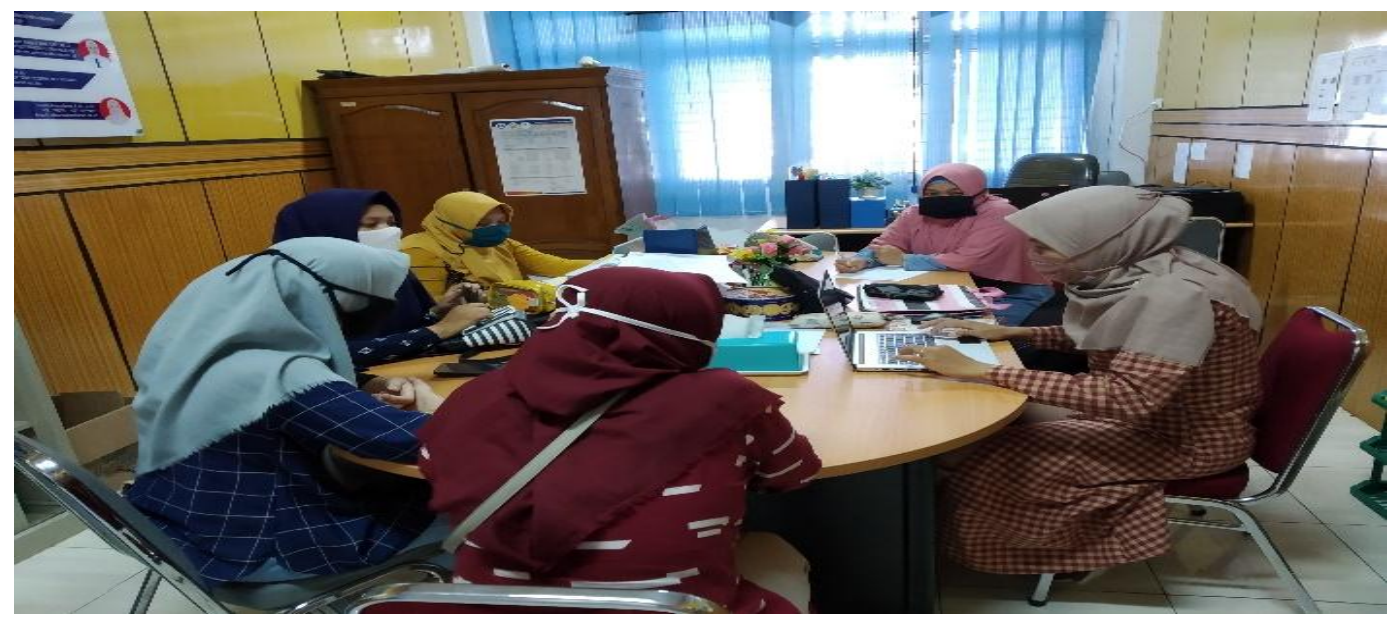

Gambar 2. Koordinasi Tim Pengabdian kepada Masyarakat 


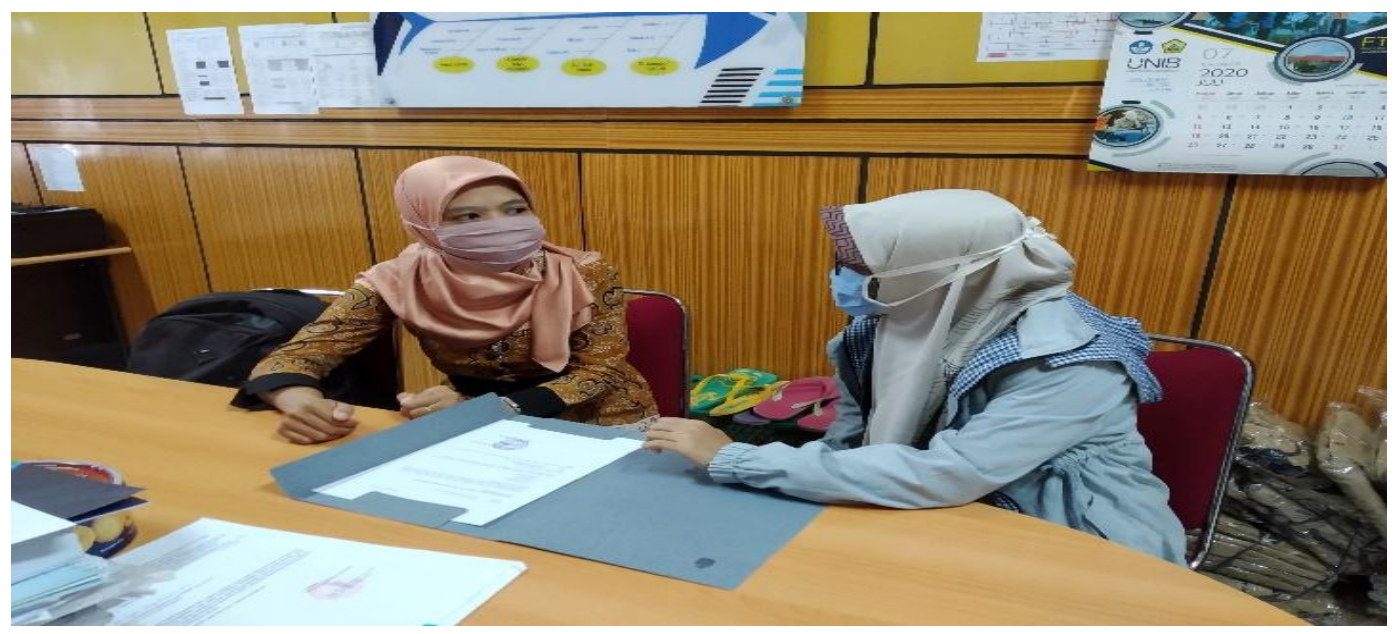

Gambar 3. Bimbingan Mahasiswa KKN Mandiri dengan Ketua Tim Pelaksana

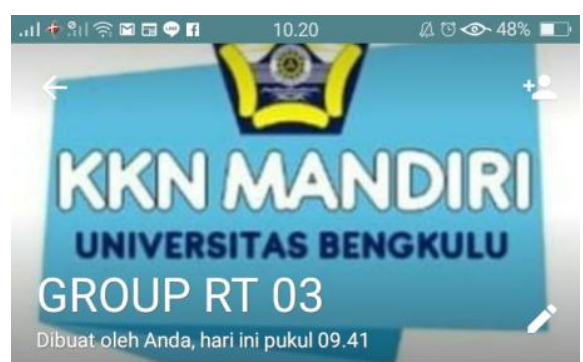

Deskripsi

Assalamualaikum Group ini dibuat sebagai

penunjang KKN Mandiri UNIB periode 91 di RT 03

kelurahan Kandang Limun Kota Bengkulu

Bisukan notifikasi
Notifikasi khusus
Tampilkan media
Enkripsi
Pesan yang dikirim ke grup ini diamankan
dengan enkripsi end-to-end. Ketuk untuk info
selengkapnya.
Setelan arun

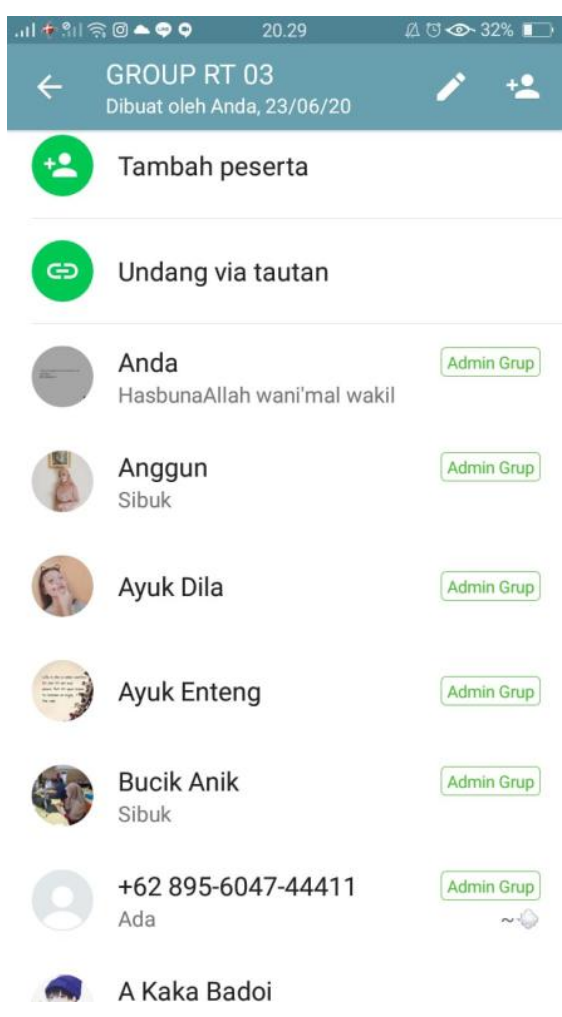

Gambar 4. WhatsApp Group RT 03

Setelah melakukan tahapan persiapan, tahap selanjutnya adalah pelaksanaan pendampingan. Tahapan ini meliputi pendampingan merancang instrumen dengan menggunakan Google Form, uji coba instrumen oleh aparat kelurahan, dan penyebaran instrumen survey secara online dengan membuat tautan di WAG. Instrumen survey dibuat 
dengan sistem online karena untuk menghindari adanya kerumunan dan menjaga jarak dalam rangka pencegahan penyebaran Covid-19. Instrumen survey dibuat dengan menggunakan salah satu fitur yang disediakan oleh Google, yaitu Google Form. Keunggulan menggunakan fitur ini adalah penggunaanya sederhana dan hasil survey dapat disimpan dengan rapi dalam format .xlsx (berupa file Excel), sehingga pengguna dapat mengelola data yang diperoleh. Setelah instrumen survey online berhasil dibuat dan diuji coba, langkah terakhir dalam tahap pelaksanaan ini adalah menyebarkan instrumen tersebut melalui tautan yang dicantumkan pada WAG RT 03.

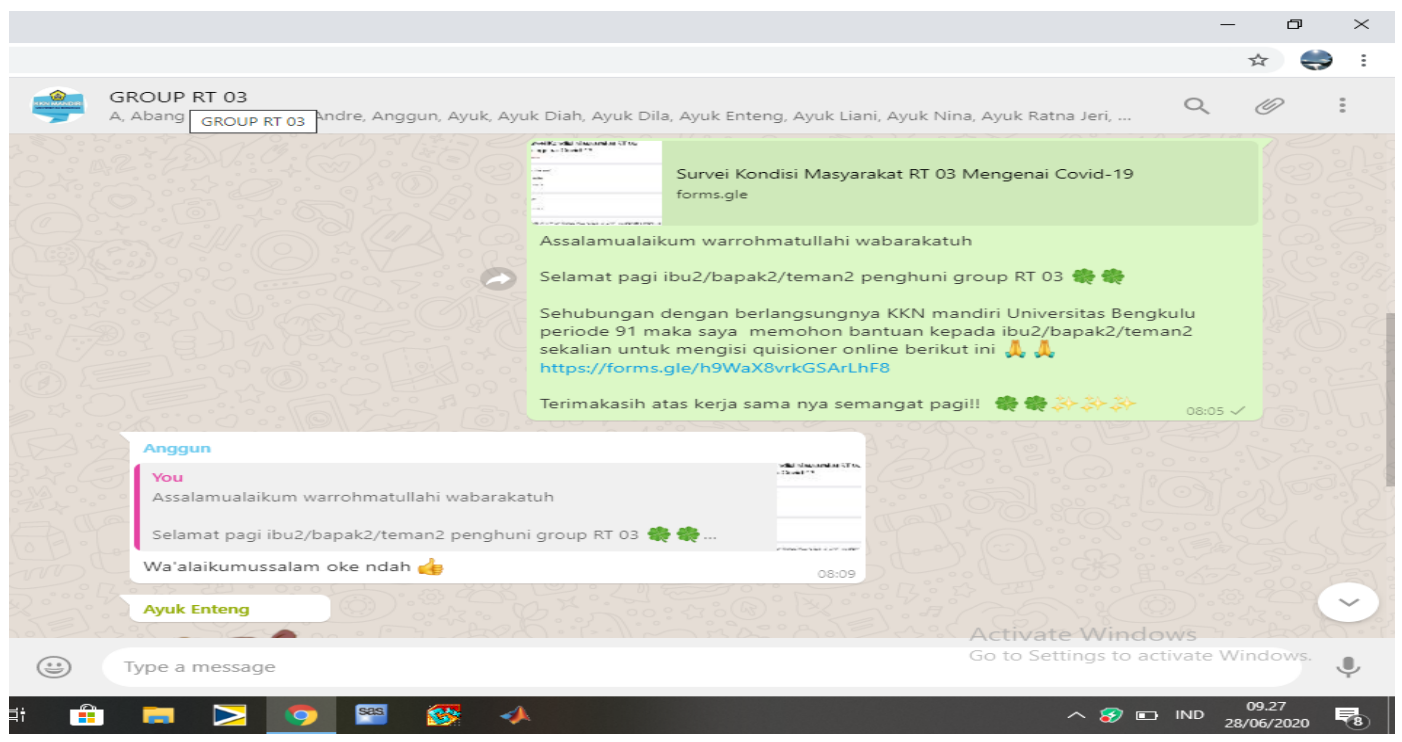

Gambar 5. Penyebaran Kuisioner melalui WAG Group RT 03

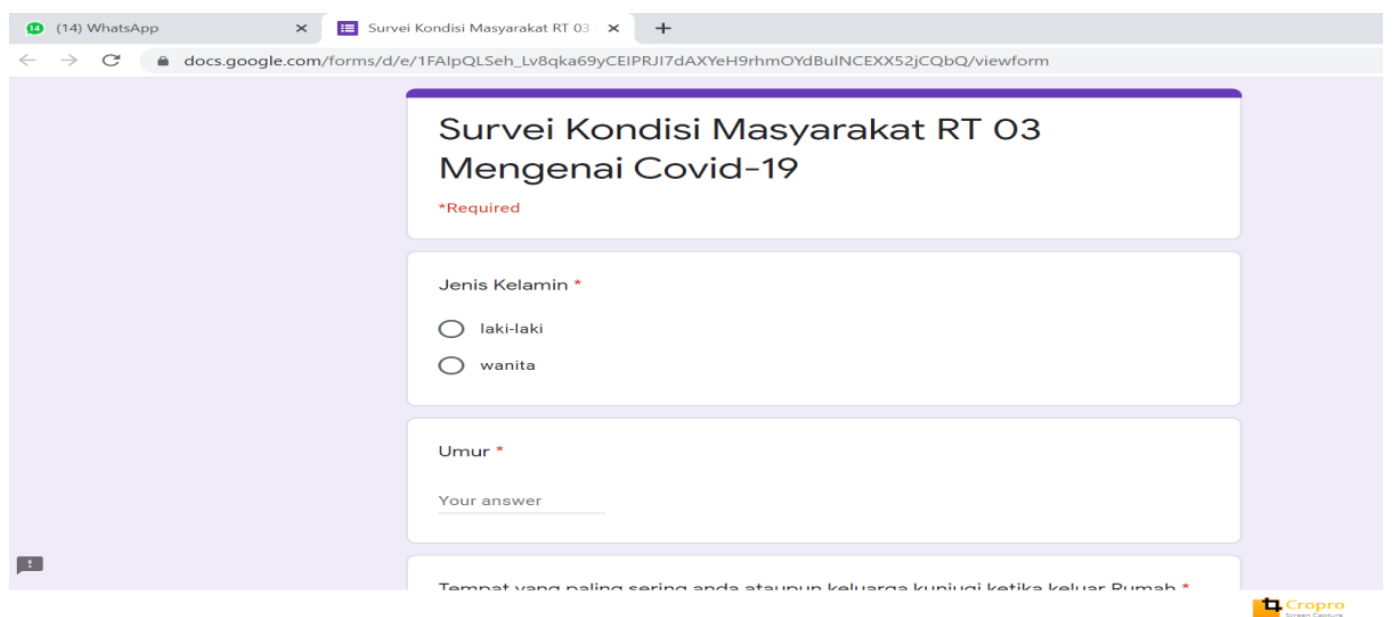

Gambar 6. Tampilan Kuisioner Online

Kuisioner online yang dibuat terdiri dari 10 pertanyaan yang dapat dijawab secara cepat (tidak memakan waktu yang lama). Pertanyaanpertanyaan tersebut antara lain sebagai berikut: 
1. Nama responden

2. Usia responden

3. Tempat yang paling sering anda ataupun keluarga kunjungi ketika keluar rumah?

4. Berapa kali keluar rumah dalam satu minggu terakhir?

5. Berapa lama durasi keluar rumah?

6. Seberapa sering anda mengikuti perkembangan info tentang Covid19 ?

7. Seberapa penting info perkembangan Covid-19 menurut anda?

8. Bagaimana kondisi anda terhadap pemberitaan tentang Covid-19?

9. Apakah anda sudah menyediakan tempat cuci tangan?

10. Apakah anda sudah menyediakan handsanitizer?

Untuk lebih lengkapnya, kuisioner online yang dibuat dengan menggunakan Google Form dapat dilihat pada tautan berikut https://forms.gle/h9WaX8vrkGSArLhF8.

Hasil pengisian kuisioner online dapat dilihat pada lampiran 1. Kuisioner online diisi oleh 75 responden yang berdomisili di RT 03 Kelurahan Kandang Limun. Beberapa jawaban pertanyaan disajikan dalam bentuk grafik sebagai berikut:

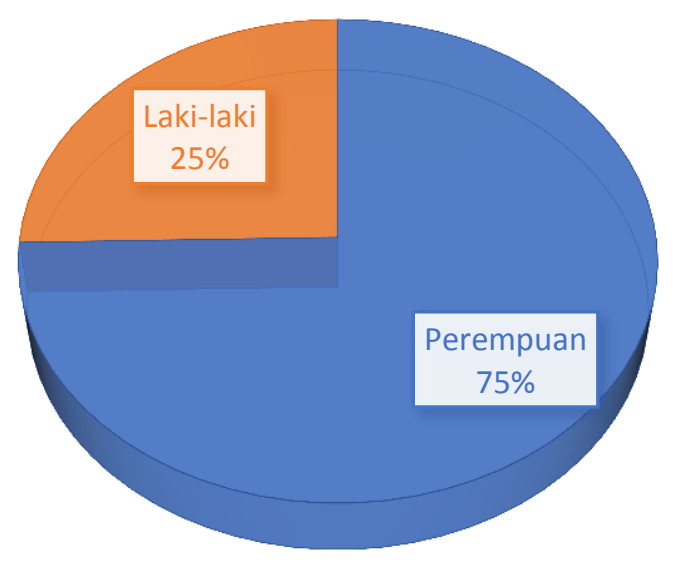

Gambar 7. Responden berdasarkan Jenis Kelamin

Berdasarkan hasil yang diperoleh, 25\% responden (19 orang) berjenis kelamin laki-laki dan $85 \%$ responden (56 orang) berjenis kelamin perempuan. Rata-rata usia responden adalah 28,89 tahun. Usia minimum responden yang mengisi kuisioner ini adalah 17 tahun sedangkan usia maksimum responden adalah 66 tahun. 


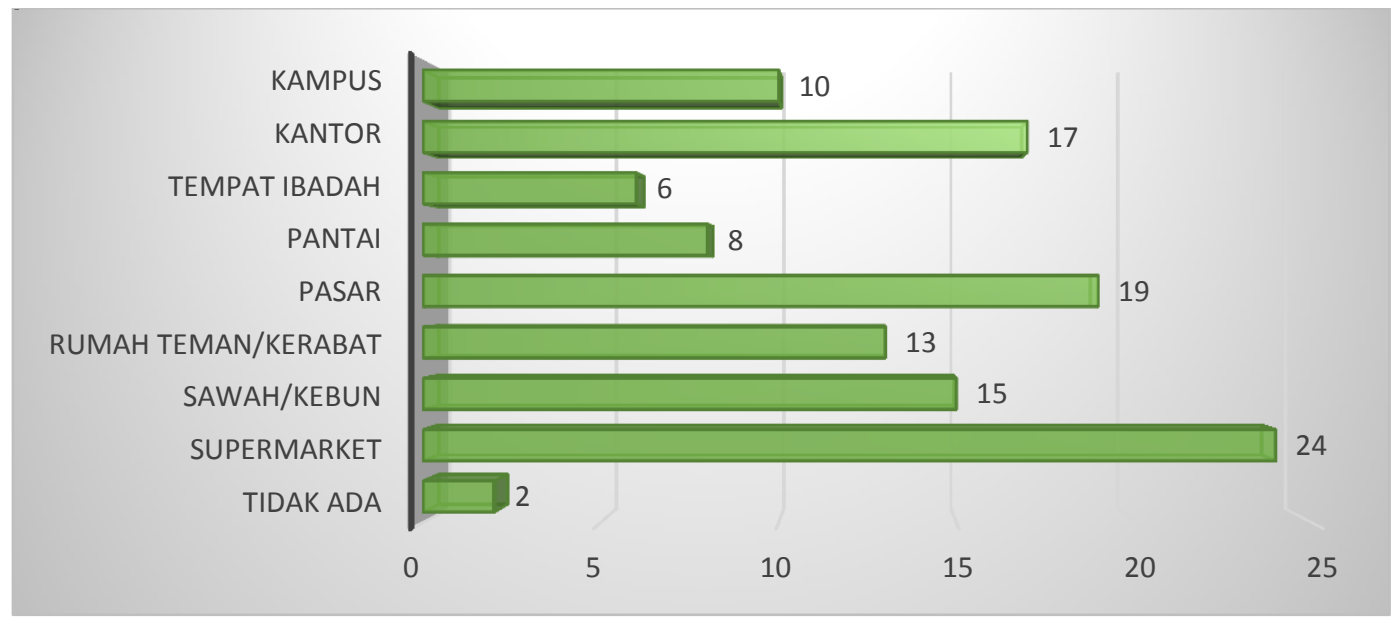

Gambar 8. Tempat umum yang Sering Dikunjungi oleh Responden pada Masa Pandemi Covid-19

Pada gambar 8 dapat dilihat bahwa 24 responden menjawab Supermarket sebagai tempat yang sering dikunjungi pada masa pandemic Covid-19 ini. Sebanyak 19 responden menjawab pasar sebagai tempat umum yang sering dikunjungi dan 17 responden menjawab Kantor sebagai tempat umum yang sering dikunjungi. Hal itu mengindikasikan bahwa selama masa pandemic Covid-19 ini warga RT 03 Kelurahan Kandang Limun masih mengunjungi tempat umum yang dapat menyebabkan kerumunan, yaitu Supermarket, Pasar dan Kantor.

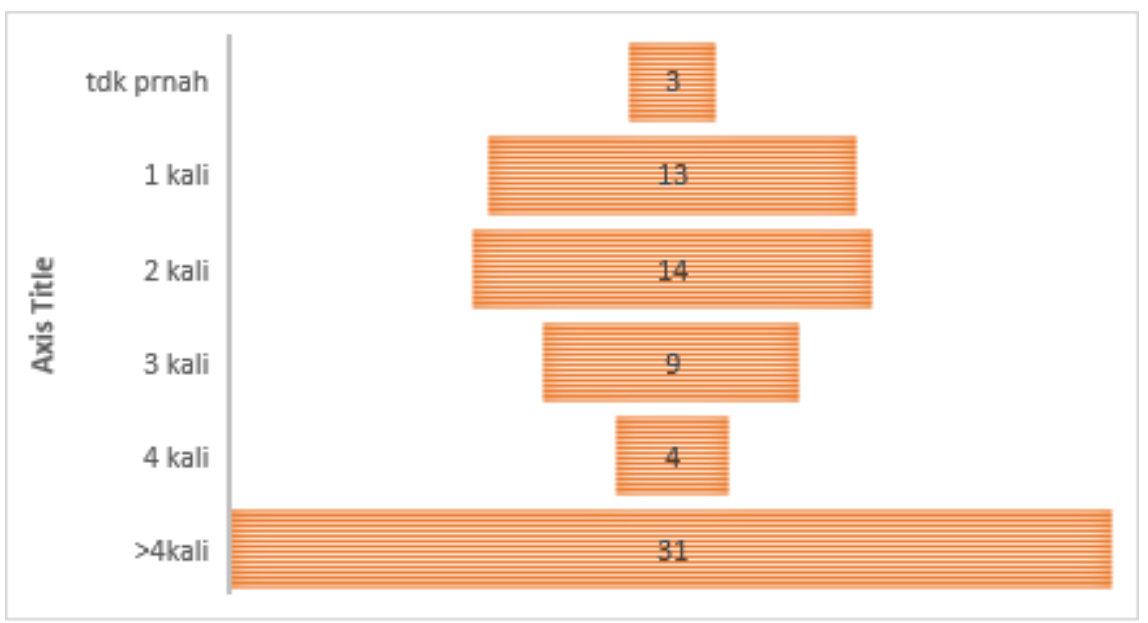

Gambar 9. Intensitas Keluar Rumah dalam Satu Minggu Terakhir

Pada gambar 9 terlihat bahwa sebanyak 31 orang responden masih sering keluar rumah pada masa pandemic Covid-19 ini. Sedangkan terdapat 3 orang responden yang tidak keluar rumah dalam satu minggu terakhir selama masa pandemic Covid-19. 
TRIBUTE : JOURNAL OF COMMUNITY SERVICES

Vol.1, No. 1, Oktober 2020: 9-21

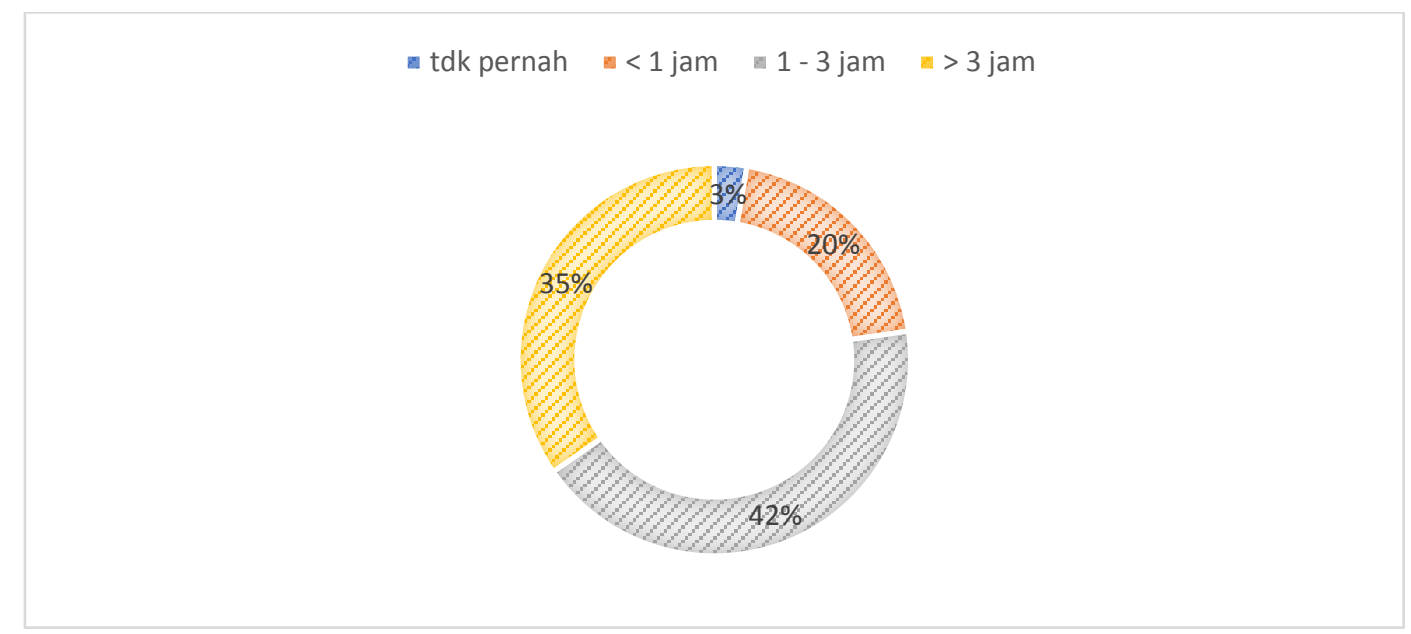

Gambar 10. Durasi Waktu Responden berada di Luar Rumah

Berdasarkan gambar 10 dapat dilihat bahwa 42\% respon menjawab 1 - 3 jam sebagai durasi waktu Ketika berada di luar rumah, sebesar 35\% menjawab lebih dari 3 jam waktu yang digunakan untuk berada di luar rumah, sebanyak $20 \%$ responden membutuhkan waktu kurang dari 1 jam Ketika berada di luar rumah, dan $2 \%$ responden tidak pernah keluar rumah pada masa pandemic ini.

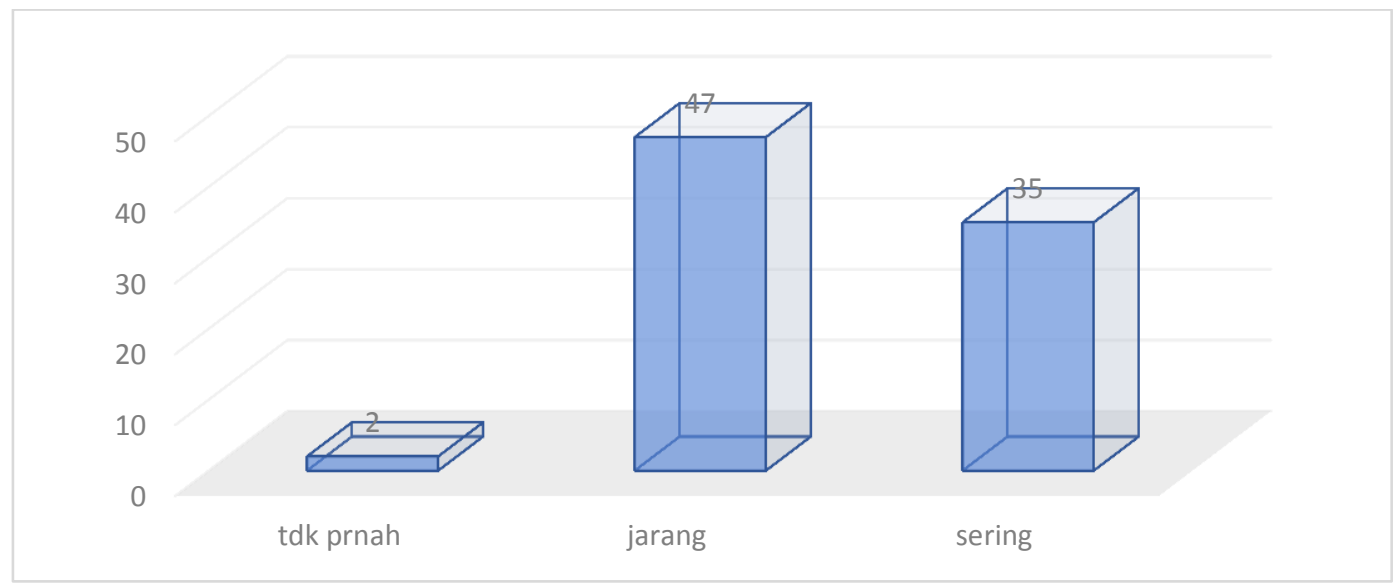

Gambar 11. Intensitas Mengikuti Perkembangan Info Covid-19

Berdasarkan gambar 11 ada 2 orang responden yang tidak pernah mengikuti perkembangan info Covid-19. Dengan kata lain, sebagian besar warga RT 03 cukup memperhatikan perkembangan info Covid-19 pada masa pandemic ini. 


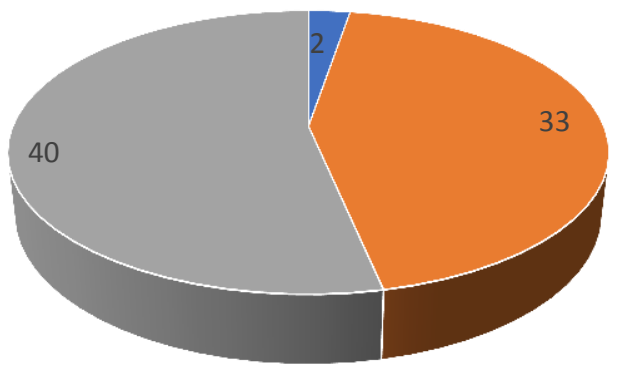

- tdk terpengaruh = sedikit berpengaruh = sangat berpengaruh

Gambar 12. Pengaruh Perkembangan Covid-19 pada Kondisi Warga RT 03 Kelurahan Kandang Limun

Pada gambar 12 dapat diketahui bahwa perkembangan Covid-19 sangat berpengaruh bagi warga RT 03 Kelurahan Kandang Limun. Hal tersebut dapat dilihat dari sebanyak 40 responden yang menjawab bahwa Pandemi Covid-19 ini sangat berpengaruh pada kondisi kehidupan seharihari mereka.

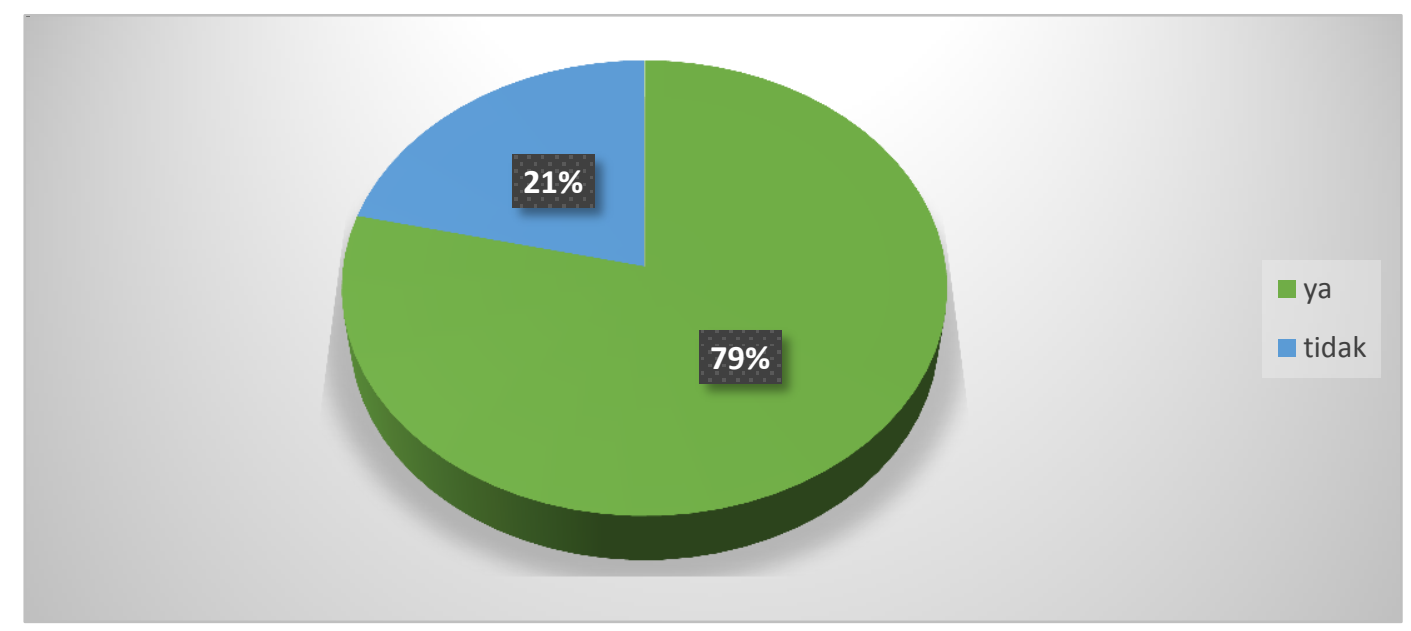

Gambar 13. Ketersediaan Handsanitizer

Berdasarkan gambar 13 dapat diketahui bahwa warga RT 03 Kelurahan Kandang Limun sudah menyediakan handsanitizer secara pribadi. Hal tersebut dapat dilihat dari sebesar $79 \%$ responden menjawab "ya" dan 21\% menjawab "tidak".

\section{KESIMPULAN}

Masa pandemi Covid-19 ini cukup mempengaruhi aktifitas warga RT 03 Kelurahan Kandang Limun. Serta Perangkat RT 03 dan Kelurahan Kandang Limun dapat menyajikan data yang diperoleh dalam bentuk grafis yang mudah dipahami oleh warga. 
TRIBUTE : JOURNAL OF COMMUNITY SERVICES

Vol.1, No. 1, Oktober 2020: 9-21

\section{DAFTAR PUSTAKA}

Margono, S. 2005. Metodologi Penelitian Pendidikan. PT. Rineka Cipta, Jakarta.

Rojabi, A. 2019. https://medium.com/@afdanrojabi/survey-researchresearch-methodology-c4d3aa5d1bb5

Saeffudin, A., K.A. Notodiputro, A. Almudi \& K. Sadik. 2009. Statistika Dasar. Grasindo, Bogor.

Soehartono, I. 2005. Metode Penelitian Sosial: Suatu Teknik Penelitian Bidang Kesejahteraan Sosial dan IImu Sosial lain. PT Remaja Rosdakarya, Bandung.

Supranto, J. 2000. Statistik: Teori dan Aplikasi. Erlangga, Jakarta.

Walpole, R.E., and R.H. Myers. 1995. Ilmu Peluang dan Statistika untuk insinyur dan Ilmuawan. ITB, Bandung.

WHO. 2019. Coronavirus Disease 2019 Pandemic. https://www.who.int/emergencies/diseases/novel-coronavirus-2019.

Wikipedia. $2019 . \quad$ Pandemi

Covid-19.

https://id.wikipedia.org/wiki/Pandemi_COVID-19. 